\title{
WILD-CAUGHT VERSUS FARMED FISH - CONSUMER PERCEPTION
}

\author{
Tomić, Marina ${ }^{1}$, Lucević, Zoran, Tomljanović, Tea ${ }^{2}$, Matulić, Daniel ${ }^{2}{ }^{*}$ \\ ${ }^{1}$ University of Zagreb, Faculty of Agriculture, Department of Agricultural Marketing, \\ Svetošimunska 25, 10000 Zagreb, Croatia \\ ${ }^{2}$ University of Zagreb, Faculty of Agriculture, Department of Fisheries, Beekeeping, Game Management and \\ Special Zoology, Svetošimunska 25, 10000 Zagreb, Croatia \\ *Corresponding Author, Email: dmatulic@agr.hr
}

\section{ARTICLE INFO}

Received: 16 February 2017

Received in revised form: 15 March 2017

Accepted: 18 April 2017

Available online: 11 May 2017

\begin{abstract}
We have limited knowledge of determinants of consumer preferences for wild-caught versus farmed-raised fish, so this work aims to investigate the impact of sociodemographics, habits and frequency of fresh fish consumption, such as involvement in cooking, on the preferences for wild versus farmed fish. A survey was done on a sample of 1151 fish consumers in Croatia. Results showed that female, older consumers, consumers with higher income and those living in coastal parts of Croatia give higher preferences for wild fish and they detect differences between the taste of wild and farmed fish. Consumers with higher levels of habits of fresh fish consumption, who eat fresh fish often and are more involved in cooking, prefer wild-caught fish. These findings provide valuable information for the aquaculture sector, especially for planning marketing strategies for the promotion of farmed fish.
\end{abstract}

Tomić, M., Lucević, Z., Tomljanović, T., Matulić, D. (2017): Wild-caught versus farmed fish - consumer perception. Croatian Journal of Fisheries, 75, 41-50. DOI: 10.1515/cjf-2017-0007.

\section{INTRODUCTION}

In recent years, consumers have started to understand that food choice may have consequences for their health (Franz and Nowak, 2010). A healthy diet is now a trend which is receiving increasing attention in the world (Kaimakoudi et al., 2013). Studies conducted among different age groups have shown that modern consumers are aware of the health benefits brought by eating fish (Smith et al., 2000; Barberger-Gateau et al., 2005; Augood et al., 2008; He, 2009). Eating fish is recommended for all age groups because it is easy to digest and contains omega-3 fatty acids, vitamins and minerals. Due to the constant increase in the human population and health benefits of eating fish, demand for fish is on the increase (Claret et al., 2014).

Unsustainable fishing practices have left capture fisheries with a shrinking resource base, which is translated into a shrinking contribution from wild fisheries to fish food security (FAO, 2004). In response to depleting wild fish stock and an increasing consumer demand for fish, they are being offered farmed fish as a viable alternative (Cahu et al., 2004).

Aquaculture is the fastest-growing animal food-producing sector with a global production which has increased from less than 1 million tonnes per year in early 1950 s to 66.6 million tonnes in 2012 (Claret et al., 2014; FAO, 2014). Accordingly, aquaculture supplied approximately $50 \%$ of the global food fish production in 2010, compared with just $9 \%$ in 1980. However, in 2012 Europe contributed only with 2880641 tonnes in quantity or $4.32 \%$ of the world's total aquaculture production (FAO, 2014). This fact can be attributed to the costs, competition for space (inland and 
coastal) with other activities, as well as the less positive image of fish from aquaculture when compared with wildcaught fish among consumers (Jaffry et al., 2004; European Commission, 2012; Uchida et al., 2014).

In spite of having a positive overall image of both fishery and aquaculture products (Ernst and Young, 2008), European consumers perceive farmed fish as being of lower general quality than wild fish (Kole, 2003; Verbeke et al., 2007a), but on the other side, Luten et al. (2002) concluded that the quality of wild and farmed cod was equally appreciated by a sample of Dutch consumers.

The term fish quality is a complex set of characteristics influenced by numerous endogenous and exogenous factors (Grigorakis, 2007). Organoleptic properties and nutritional values are the characteristics that, together with freshness, compose fish quality perception. The quality dimensions mainly rely on the chemical composition, environmental factors and feeding, but there are other important aspects such as species, age, sex, etc. (Di Turi, 2009). Most of previous studies compared quality of wild and farmed fish according to chemical composition, nutritional value and other physical-chemical parameters (Poli et al., 2001; Alasalvar et al., 2002; Grigorakis et al., 2003; Johnston et al., 2006; Grigorakis, 2007; Fuentes et al., 2010).

Consumer perception of a wild-caught versus farmed fish and its acceptance or rejection is of a multi-factorial nature. Previous research has shown that sociodemographic characteristics (gender, age, education level, income, place of residence) have a high influence on consumer preferences for wild-caught versus farmed fish. Davidson et al. (2012) reported that Hawaiian consumers prefer wild to farmed fish. Claret et al. (2014) concluded that consumers with a higher objective knowledge about fish and a higher level of education were more ready to agree with scientific evidence and consequently more likely to make better and reasoned fish choices. According to Drichoutis et al. (2006), females have a higher openness to farmed fish because females have higher involvement in cooking (they are mainly responsible for food shopping and preparation of food within the household). Claret et al. (2014) also stressed female gender as more used to aquaculture products and their advantages. Cardoso et al. (2013) concluded that geographical factors, such as coastal versus inland location, affected preferences and consumption patterns of some products. Coastal populations prefer wild fish and eat less farmed fish products compared to inland populations.

Kaimakoudi et al. (2013) have identified the two Greek clusters of low-potential and high-potential aquaculture consumers. Most of the consumers belonged to the low-potential cluster. Their results indicated that the high-potential aquaculture consumers tended to have a higher income, were younger and had higher educational attainment than the low-potential aquaculture consumers. However, both clusters revealed a greater preference for catches versus aquaculture products.

Furthermore, results from Rajani (2010) showed a significantly higher attitude and intention as well as consumption of wild fish than that of farmed fish. The beliefs of quality and availability of wild fish were significantly more positive when compared with farmed fish. Middle-aged consumers, who usually show a higher food involvement than younger consumers, held stronger beliefs, both favourable and unfavourable, about fish from aquaculture (Drichoutis, et al., 2006). Although previous research showed consumer preferences for wild-caught versus farmed fish (Rajani et al., 2010; Uchida et al., 2014; Claret et al., 2016), there is a lack of detailed empirical research regarding consumer characteristics related to preferences for wild-caught versus farmed fish. This paper focuses on determinants of preferences for wild-caught and farmraised fish on the sample of Croatian consumers.

\section{MATERIALS AND METHODS}

A survey was conducted online (90\% of respondents) and face to face ( $10 \%$ of respondents) using a self-administered questionnaire. Data were collected between 1 April and 30 April 2014. Web link for the questionnaire was distributed via Facebook and Linkedln and sent via email to the appropriate subjects. For face-to-face survey a convenience sample was used, and for online survey - snowball sampling. The time needed for filling the questionnaire was 5-7 minutes. The survey was divided and grouped into the following categories: habits of fresh fish consumption, involvement in cooking, preferences for wild fish versus farmed fish, physical activity and sociodemographic variables (gender, age, education, number of household members, income, place raised, place of living and residence).

Respondent's involvement in cooking was collected by means of 3 items taken from Grunert et al. (1993). Respondents had to express their agreement with statements on a five-point Likert scale that ranged from (1) - completely disagree to (5) - completely agree. Three items were used to measure habits of fresh fish consumption constructed for this research. Higher values indicated a higher consumption frequency of fresh fish. Preferences for wild fish versus farmed fish were measured by two items constructed for the purpose of this research ("When purchasing fresh fish I prefer purchasing species that are not farmed", "When I eat fresh fish I do not detect the difference in the taste between the wild and farmed fish"). Higher scores indicated higher frequency of the purchase of fish species that are not farmed (wild) and detection of differences in the taste between the wild and farmed fish.

All data analyses were done in SPSS statistical package, version 21. Univariate statistics (frequencies) were used for sample description and analysis of fresh fish consumption (frequency of fresh fish consumption in the last month). 
Descriptive analysis was used to explore consumer habits to eat fresh fish, involvement in cooking and preferences for wild-caught fish versus farmed fish. Bivariate statistics (Chi-square test, ANOVA) were used to check the impact of sociodemographic characteristics, habits of fresh fish consumption, frequency of fresh fish consumption and involvement in cooking on preferences for wild fish versus farmed fish.

\section{RESULTS}

\section{Sample description}

In the total number of respondents $(\mathrm{N}=1151)$, there are more females (69.5\%) than males (30.5\%).

Table 1. Sociodemographic characteristics of the sample

\begin{tabular}{|c|c|c|c|}
\hline \multicolumn{2}{|c|}{ Sociodemographic characteristics } & \multirow{2}{*}{$\begin{array}{c}N=1151 \\
800\end{array}$} & \multirow{2}{*}{$\begin{array}{c}\% \\
69.5\end{array}$} \\
\hline Gander & Female & & \\
\hline sentaer & Male & 351 & 30.5 \\
\hline \multirow{4}{*}{ Age } & $18-29$ & 530 & 46.0 \\
\hline & $30-45$ & 449 & 39.0 \\
\hline & $46-60$ & 140 & 12.2 \\
\hline & +60 & 32 & 2.8 \\
\hline \multirow{4}{*}{ Education } & Elementary school & 11 & 1.0 \\
\hline & High school & 259 & 22.5 \\
\hline & University & 558 & 48.5 \\
\hline & Master and/or PhD & 323 & 28.1 \\
\hline \multirow{4}{*}{$\begin{array}{l}\text { Number of } \\
\text { household } \\
\text { members }\end{array}$} & 1 & 49 & 4.3 \\
\hline & 2 & 226 & 19.6 \\
\hline & $3-5$ & 794 & 69.0 \\
\hline & $>5$ & 82 & 7.1 \\
\hline \multirow{5}{*}{ Income } & Very low & 22 & 1.9 \\
\hline & Low & 101 & 8.8 \\
\hline & Average & 819 & 71.2 \\
\hline & High & 182 & 15.8 \\
\hline & Very high & 27 & 2.3 \\
\hline \multirow{3}{*}{$\begin{array}{l}\text { Place } \\
\text { raised }\end{array}$} & Continental Croatia & 725 & 63.0 \\
\hline & Coastal Croatia & 369 & 32.1 \\
\hline & I was not raised in Croatia & 57 & 5.0 \\
\hline \multirow{3}{*}{$\begin{array}{l}\text { Place of } \\
\text { living }\end{array}$} & Continental Croatia & 820 & 71.2 \\
\hline & Coastal Croatia & 316 & 27.5 \\
\hline & I don't live in Croatia & 15 & 1.3 \\
\hline \multirow{2}{*}{ Residence } & Urban & 937 & 81.4 \\
\hline & Rural & 214 & 18.6 \\
\hline
\end{tabular}

The most represented age group is the 18-29 years old $(46 \%)$. Most of the respondents have average income (71.2\%), university education (48.5\%), live in a household with 3-5 members (69\%), were raised $(32.1 \%)$ and live in a continental part of Croatia (71.2\%), and $81.4 \%$ have a urban residence (Table 1 ). One third of the respondents participated in some physical activity 2-3 times per week, $11.2 \%$ is not engaged in any physical activities, while $11 \%$ of respondents participated in some physical activity less than once a week.

\section{Fresh fish consumption}

Most of the respondents ate fresh fish in the last month 2-3 times; $22.4 \%$ ate fresh fish in the last month 4-5 times, $20.8 \%$ of the respondents ate fresh fish only once in the last month, whereas $8.5 \%$ of respondents did not eat fresh fish in the last month (Fig. 1).

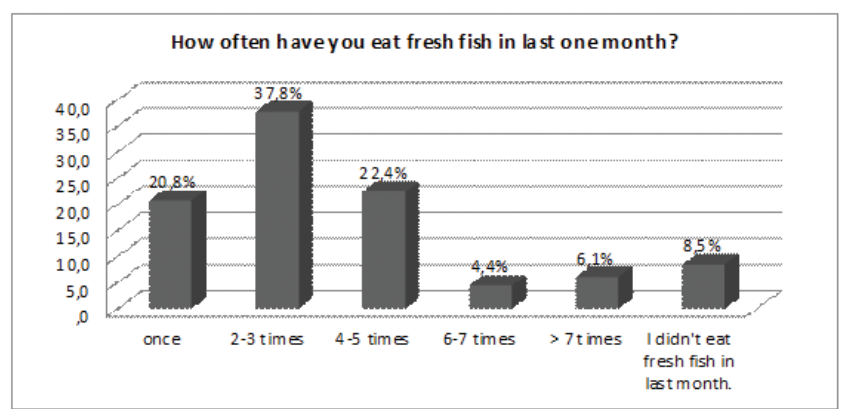

Fig 1. Frequency of fresh fish consumption at home

\section{Habits of fresh fish consumption}

On average, the fresh fish consumption of the respondents is present (mean 3.67). They ate fresh fish on a regular basis in childhood (mean 3.57), but they do not regularly try new species of fish (mean 2.70) - Table 2.

Table 2. Habits of fresh fish consumption

\begin{tabular}{lccccc}
\hline & N & Minimum & Maximum & Mean & $\begin{array}{c}\text { Std. } \\
\text { Deviation }\end{array}$ \\
\hline $\begin{array}{l}\text { I have a habit } \\
\text { to eat fresh } \\
\text { fish. }\end{array}$ & 1151 & 1 & 5 & 3.67 & 0.97 \\
$\begin{array}{l}\text { I ate fresh fish } \\
\text { on regular } \\
\text { basis as a child. }\end{array}$ & 1151 & 1 & 5 & 3.57 & 1.16 \\
$\begin{array}{l}\text { I regularly try } \\
\text { new species of }\end{array}$ & 1151 & 1 & 5 & 2.70 & 1.00 \\
fish. & & & & & \\
\hline $\begin{array}{l}\text { Source: survey } \\
\text { Sour }\end{array}$ & & & & & \\
\hline
\end{tabular}




\section{Involvement in cooking}

The respondents show to have a medium level of involvement in cooking (mean 2.84). They have a higher level of agreement with an item "I deliberately avoid complicated recipes" (mean 3.38) compared to other items in the involvement in cooking scale. Mean value of an item "At home we usually eat quickly prepared meals rather than more carefully prepared dishes" is 2.70. Respondents do not think they have better ways to spend their time than doing grocery shopping and cooking (mean 2.43) - Table 3.

Table 3. Involvement in cooking

\begin{tabular}{lccccc}
\hline & N & $\begin{array}{c}\text { Mini- } \\
\text { mum }\end{array}$ & $\begin{array}{c}\text { Maxi- } \\
\text { mum }\end{array}$ & Mean & $\begin{array}{c}\text { Std. } \\
\text { Deviation }\end{array}$ \\
\hline $\begin{array}{l}\text { I deliberately avoid } \\
\text { complicated recipes. }\end{array}$ & 1151 & 1 & 5 & 3.38 & 0.91 \\
$\begin{array}{l}\text { At home we usually } \\
\text { eat quickly prepared } \\
\text { meals rather than } \\
\text { more carefully } \\
\text { prepared dishes. }\end{array}$ & 1151 & 1 & 5 & 2.70 & 1.10 \\
$\begin{array}{l}\text { I have better ways } \\
\text { to spend my time } \\
\text { than doing grocery } \\
\text { shopping and } \\
\text { cooking. }\end{array}$ & 1151 & 1 & 5 & 2.43 & 0.98 \\
\hline \hline
\end{tabular}

\section{Preferences for wild-caught fish versus farmed fish}

Generally, respondents have neutral preferences for wild fish versus farmed fish. When they buy fresh fish, they are neutral regarding species of fish that are not farmed (mean 3.02). A similar result is achieved with consumption of fresh fish. When they consume fresh fish, they are neutral about differences in taste of wild and farmed fish (mean 3.04) Table 4.

Table 4. Preferences for wild-caught fish versus farmed fish

\begin{tabular}{lccccc}
\hline \hline & $\mathbf{N}$ & $\begin{array}{c}\text { Mini- } \\
\text { mum }\end{array}$ & $\begin{array}{c}\text { Maxi- } \\
\text { mum }\end{array}$ & Mean & $\begin{array}{c}\text { Std. } \\
\text { Deviation }\end{array}$ \\
\hline $\begin{array}{l}\text { When buying fresh } \\
\text { fish I prefer species } \\
\text { that are not farmed. }\end{array}$ & 1151 & 1 & 5 & 3.02 & 1.06 \\
$\begin{array}{l}\text { When I consume } \\
\text { fresh fish I do not } \\
\text { detect differences } \\
\text { in wild and farmed }\end{array}$ & 1151 & 1 & 5 & 3.04 & 1.12 \\
fish.* & & & & & \\
\end{tabular}

$$
\text { *recoded }
$$

\section{Impact of sociodemographic characteristics and physical activity}

According to Table 5, gender is positively related to preferences for wild-caught fish $(p<0.05)$. Male respondents have a higher level of agreement with an item "When I consume fresh fish, I do not detect differences in the taste of wild and farmed fish" (mean 3.18) compared to female respondents (mean 2.97).

Older respondents (46+) are the ones who, while shopping, care the most about fish species $(p<0.05)$. Older respondents also tend to detect the differences in taste of wild and farmed fish more often than younger respondents $(p<0.05)$. Respondents with a higher income detect differences in the taste of wild and farmed fish during fish consumption more frequently $(p<0.05)$. People who were raised in coastal Croatia, while shopping for food, prefer wild fish species $(p<0.05)$ unlike the respondents from continental Croatia. They also detect more often the differences in taste of wild and farmed fish during fish consumption $(p<0.05)$. People from coastal Croatia, while shopping, prefer wild fish species unlike the people from continental Croatia $(p<0.05)$.

Respondents who participate in physical activity more than 4 times per week prefer to purchase fish species that are not farmed $(p<0.05)$. Impact of habits of fresh fish consumption on
preferences for wild-caught fish

ANOVA test showed habits of fresh fish consumption influence significantly the preferences for wild-caught fish $(p<0.05)$. Respondents with higher levels of habits of fresh fish consumption prefer to purchase fish species that are not farmed and they detect more often the differences between wild and farmed fish $(\mathrm{p}<0.05)$.

People that ate fresh fish on a regular basis during childhood also prefer wild fish species and they more often detect whether there are some differences $(p<0.05)$. Similar results are achieved with respondents who regularly try new fish species $(p<0.05)$ (Table 6).

\section{Impact of involvement in cooking on preferences for wild-caught fish}

The results of this study showed there is a significant relation between involvement in cooking and preferences for wildcaught fish $(p<0.05)$. Respondents who do not deliberately avoid complicated recipes more often detect whether there are differences in wild and farmed fish $(p<0.05)$. Similar results have been found among eating quickly prepared meals and importance of fish farming. Respondents that rarely eat quickly prepared meals at home prefer fish species 
Table 5. Impact of sociodemographic characteristics and frequency of physical activity on preferences for wild-caught fish versus farmed fish

\begin{tabular}{|c|c|c|c|c|c|c|c|}
\hline & & \multicolumn{2}{|c|}{$\begin{array}{l}\text { When buying fresh fish I } \\
\text { prefer species that are not } \\
\text { farmed. }\end{array}$} & \multirow[t]{2}{*}{ p } & \multicolumn{2}{|c|}{$\begin{array}{l}\text { When I consume fresh fish I do } \\
\text { not detect differences in wild } \\
\text { and farmed fish. }\end{array}$} & \multirow[t]{2}{*}{ p } \\
\hline & & Mean & Std. Deviation & & Mean & Std. Deviation & \\
\hline \multirow{6}{*}{ 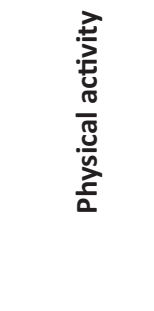 } & Every day & 3.31 & 1.06 & \multirow{6}{*}{$<0.05$} & 3.10 & 1.14 & \multirow{6}{*}{$>0.05$} \\
\hline & 4-5 times per week & 3.31 & 0.94 & & 3.10 & 1.11 & \\
\hline & 2-3 times per week & 2,93 & 1.06 & & 3.08 & 1.12 & \\
\hline & Once a week & 2.87 & 1.02 & & 3.03 & 1.07 & \\
\hline & Less than once a week & 3.02 & 1.12 & & 2.97 & 1.12 & \\
\hline & $\begin{array}{l}\text { I do not engage in any physical } \\
\text { activity }\end{array}$ & 2,85 & 1.05 & & 2.91 & 1.20 & \\
\hline \multirow{3}{*}{ Gender } & Male & 2.95 & 1.02 & \multirow{2}{*}{$>0.05$} & 3.18 & 1.12 & \multirow{2}{*}{$<0.05$} \\
\hline & Female & 3.05 & 1.07 & & 2.98 & 1.12 & \\
\hline & $18-29$ years & 2.98 & 1.03 & \multirow{4}{*}{$<0.05$} & 2.97 & 1.13 & \multirow{4}{*}{$<0.05$} \\
\hline \multirow{3}{*}{ Age } & $30-45$ years & 2.97 & 1.03 & & 3.05 & 1.11 & \\
\hline & $46-60$ years & 3.27 & 1.13 & & 3.18 & 1.06 & \\
\hline & +60 years & 3.31 & 1.28 & & 3.47 & 1.24 & \\
\hline \multirow{4}{*}{ Education } & El. school & 2.36 & 1.29 & \multirow{4}{*}{$>0.05$} & 2.9 & 1.37 & \multirow{4}{*}{$>0.05$} \\
\hline & High school & 3.13 & 0.99 & & 3.09 & 1.11 & \\
\hline & University & 3.02 & 1.05 & & 3.05 & 1.11 & \\
\hline & $\mathrm{Ms} / \mathrm{PhD}$ & 2.97 & 1.11 & & 2.99 & 1.15 & \\
\hline \multirow{4}{*}{$\begin{array}{l}\text { No. of } \\
\text { household } \\
\text { members }\end{array}$} & 1 & 2.96 & 1.17 & \multirow{4}{*}{$>0.05$} & 3.16 & 1.12 & \multirow{4}{*}{$>0.05$} \\
\hline & 2 & 3.04 & 1.05 & & 3.13 & 1.05 & \\
\hline & $3-5$ & 3.02 & 1.06 & & 3.01 & 1.14 & \\
\hline & $>5$ & 3.04 & 0.94 & & 3.08 & 1.15 & \\
\hline \multirow{5}{*}{ Income } & Very low & 3.09 & 1,02 & \multirow{5}{*}{$>0.05$} & 2.95 & 1.04 & \multirow{5}{*}{$<0.05$} \\
\hline & Low & 2.86 & 1.01 & & 2.85 & 1.09 & \\
\hline & Average & 3.02 & 1.04 & & 2.99 & 1.10 & \\
\hline & High & 3.08 & 1.11 & & 3.35 & 1.16 & \\
\hline & Very high & 3.26 & 1.20 & & 3.15 & 1.32 & \\
\hline \multirow{3}{*}{$\begin{array}{l}\text { Place } \\
\text { raised }\end{array}$} & Continental Croatia & 2.92 & 1.03 & \multirow{3}{*}{$<0.05$} & 2.96 & 1.10 & \multirow{3}{*}{$<0.05$} \\
\hline & Coastal Croatia & 3.22 & 1.10 & & 3.19 & 1.17 & \\
\hline & I was not raised in Croatia & 2.98 & 0.97 & & 3.16 & 0.99 & \\
\hline \multirow{3}{*}{$\begin{array}{l}\text { Place of } \\
\text { living }\end{array}$} & Continental Croatia & 2.97 & 1.05 & \multirow{3}{*}{$<0.05$} & 2.99 & 1.11 & \multirow{3}{*}{$>0.05$} \\
\hline & Coastal Croatia & 3.16 & 1.06 & & 3.15 & 1.16 & \\
\hline & I don't live in Croatia & 3.20 & 0.86 & & 3.20 & 1.08 & \\
\hline Pecidence & Urban & 3.04 & 1.07 & $>005$ & 3.05 & 1.10 & $>005$ \\
\hline Resiaence & Rural & 2.96 & 1.00 & $>0.05$ & 3.03 & 1.22 & $>0.05$ \\
\hline
\end{tabular}

that are not farmed when buying fresh fish $(p<0.05)$. They also more often detect differences in wild and farmed fish $(\mathrm{p}<0.05)$. People who agree with an item "I have better ways to spend my time than doing grocery shopping and cooking" care less about fish species that are not farmed and they are neutral regarding recognition of differences in wild and farmed fish $(p<0.05)$ (Table 7).
Impact of frequency of fresh fish consumption on preferences for wild-caught fish

According to Table 8, frequency of fresh fish consumption is in significant relation with preferences for wild-caught fish $(p<0.05)$. Respondents who ate fresh fish more often 
Table 6. Impact of habits of fresh fish consumption on preferences for wild-caught fish versus farmed fish

\begin{tabular}{|c|c|c|c|c|c|c|c|}
\hline \multirow{2}{*}{$\begin{array}{l}\text { Habits of fresh fish } \\
\text { consumption }\end{array}$} & \multicolumn{4}{|c|}{ When buying fresh fish I prefer species that are not farmed. } & \multicolumn{3}{|c|}{$\begin{array}{l}\text { When I consume fresh fish I do } \\
\text { not detect differences in wild and } \\
\text { farmed fish.* }\end{array}$} \\
\hline & & Mean & $\begin{array}{l}\text { Std. } \\
\text { Deviation }\end{array}$ & p & Mean & $\begin{array}{l}\text { Std. } \\
\text { Deviation }\end{array}$ & p \\
\hline \multirow{6}{*}{$\begin{array}{l}\text { I have a habit to eat } \\
\text { fresh fish. }\end{array}$} & Completely disagree & 1.92 & 0.93 & & 2.92 & 1.58 & \\
\hline & Disagree & 2.70 & 0.98 & & 2.67 & 1.02 & \\
\hline & Neither agree, neither disagree & 2.87 & 0.87 & $<0.05$ & 2.87 & 1.02 & $<0.05$ \\
\hline & Agree & 3.05 & 0.95 & & 3.08 & 0.99 & \\
\hline & Completely agree & 3.44 & 1.33 & & 3.41 & 1.38 & \\
\hline & Completely disagree & 2.58 & 1.16 & & 2.74 & 1.43 & \\
\hline \multirow{4}{*}{$\begin{array}{l}\text { I ate fresh fish on } \\
\text { a regular basis as a } \\
\text { child }\end{array}$} & Disagree & 2.87 & 1.02 & & 2.98 & 1.07 & \\
\hline & Neither agree, neither disagree & 3.00 & 0.88 & $<0.05$ & 3.14 & 1.02 & $<0.05$ \\
\hline & Agree & 3.08 & 0.94 & & 3.08 & 1.11 & \\
\hline & Completely agree & 3.15 & 1.28 & & 3.23 & 1.43 & \\
\hline \multirow{5}{*}{$\begin{array}{l}\text { I regularly try new } \\
\text { species of fish. }\end{array}$} & Completely disagree & 2.37 & 1.19 & & 2.70 & 1.28 & \\
\hline & Disagree & 2.93 & 1.03 & & 2.98 & 1.06 & \\
\hline & Neither agree, neither disagree & 3.08 & 0.94 & $<0.05$ & 2.91 & 0.99 & $<0.05$ \\
\hline & Agree & 3.24 & 1.01 & & 3.02 & 1.01 & \\
\hline & Completely agree & 3.85 & 1.08 & & 3.30 & 1.32 & \\
\hline
\end{tabular}

*recoded

Table 7. Impact of involvement in cooking on preferences for wild-caught fish versus farmed fish

\begin{tabular}{|c|c|c|c|c|c|c|c|}
\hline \multirow[t]{2}{*}{ Involvement in cooking } & \multicolumn{4}{|c|}{$\begin{array}{l}\text { When buying fresh fish I prefer species that are not } \\
\text { farmed. }\end{array}$} & \multicolumn{3}{|c|}{$\begin{array}{l}\text { When I consume fresh fish I do } \\
\text { not detect differences in wild and } \\
\text { farmed fish.* }\end{array}$} \\
\hline & & Mean & $\begin{array}{l}\text { Std. } \\
\text { Deviation }\end{array}$ & p & Mean & $\begin{array}{l}\text { Std. } \\
\text { Deviation }\end{array}$ & $\mathbf{p}$ \\
\hline \multirow{5}{*}{$\begin{array}{l}\text { I deliberately avoid } \\
\text { complicated recipes. }\end{array}$} & Completely disagree & 2.98 & 1.24 & & 3.62 & 1.25 & \multirow{5}{*}{$<0.05$} \\
\hline & Disagree & 3.18 & 1.02 & & 3.29 & 1.05 & \\
\hline & $\begin{array}{l}\text { Neither agree, neither } \\
\text { disagree }\end{array}$ & 3.04 & 0.97 & $>0.05$ & 2.99 & 1.06 & \\
\hline & Agree & 2.99 & 1.07 & & 2.95 & 1.13 & \\
\hline & Completely agree & 2.89 & 1.18 & & 3.28 & 1.07 & \\
\hline \multirow{5}{*}{$\begin{array}{l}\text { At home we usually eat } \\
\text { quickly prepared meals } \\
\text { rather than more carefully } \\
\text { prepared dishes. }\end{array}$} & Completely disagree & 3.14 & 1.25 & & 3.42 & 1.26 & \multirow{5}{*}{$<0.05$} \\
\hline & Disagree & 3.12 & 0.99 & & 3.08 & 1.05 & \\
\hline & $\begin{array}{l}\text { Neither agree, neither } \\
\text { disagree }\end{array}$ & 3.01 & 0.99 & $<0.05$ & 3.05 & 1.05 & \\
\hline & Agree & 2.89 & 1.03 & & 2.81 & 1.10 & \\
\hline & Completely agree & 2.20 & 1.30 & & 2.40 & 0.55 & \\
\hline \multirow{5}{*}{$\begin{array}{l}\text { I have better ways to spend } \\
\text { my time than doing grocery } \\
\text { shopping and cooking. }\end{array}$} & Completely disagree & 3.25 & 1.22 & & 3.28 & 1.32 & \multirow{5}{*}{$<0.05$} \\
\hline & Disagree & 3.04 & 0.98 & & 3.10 & 1.02 & \\
\hline & $\begin{array}{l}\text { Neither agree, neither } \\
\text { disagree }\end{array}$ & 2.94 & 1.00 & $<0.05$ & 2.98 & 1.04 & \\
\hline & Agree & 2.86 & 1.04 & & 2.75 & 1.14 & \\
\hline & Completely agree & 2.00 & 1.73 & & 3.00 & 1.00 & \\
\hline
\end{tabular}


Table 8. Impact of frequency of fresh fish consumption on preferences for wild-caught fish versus farmed fish

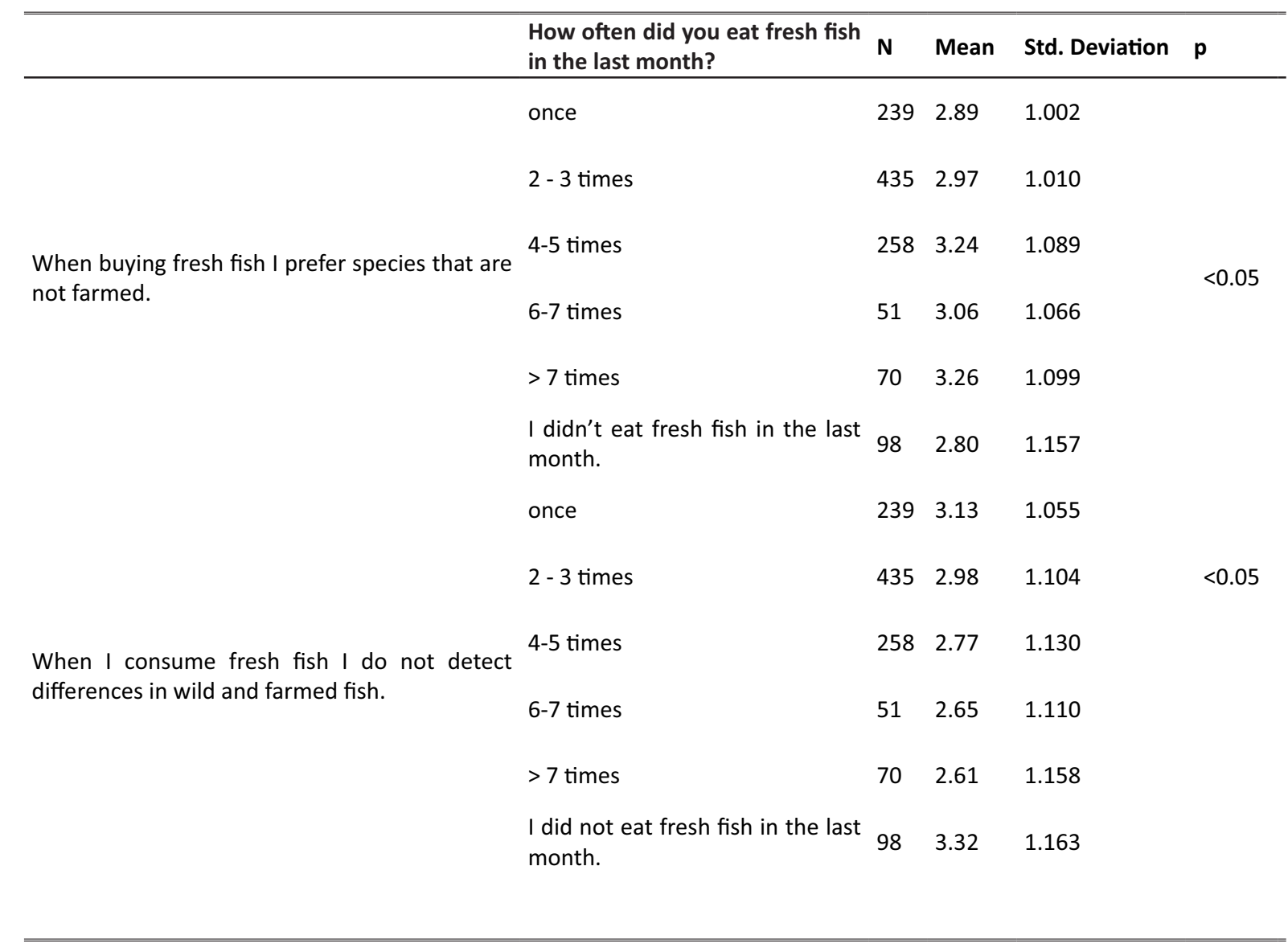

in the last month ( 4 times or more) prefer fish species that are not farmed during the process of purchase, compared to the respondents who did not eat fresh fish in the last month or they ate it less than 4 times. People who ate fresh fish 4 times or more in the last month, more often detect differences in wild and farmed fish.

\section{DISCUSSION}

In this study, determinants of preferences of consumers in Croatia for wild-caught versus farmed fresh fish have been investigated. The results of this study give indications of fresh fish consumption behaviour, habits of fresh fish consumption and preferences for wild-caught versus farmedraised fish on a sample of Croatian fresh-fish consumers. Furthermore, the results of the present study show influence of sociodemographic characteristics, habits of fresh fish consumption, involvement in cooking and frequency of fresh-fish consumption on consumer preferences, which provide a deeper understanding of consumer behaviour in fresh fish consumption.

The study shows that, in the sample, most Croatian consumers (almost 40\%) ate fresh fish at home 2-3 times in the last month. These results are not consistent with Eurofish data according to which Croatian consumers eat fish mostly once a week and during some holidays. According to Food Standards Australia New Zealand (2011), 2 to 3 servings per week of any fish and seafood are recommended; so the average consumption of fresh fish in Croatia seems to be below the recommendations. Due to these results, increasing the frequency of fresh consumption should be the goal of policymakers.

Furthermore, Croatian consumers have a habit of consuming fresh fish often, also during childhood. This is in line with previous studies according to which the habit, especially during childhood, of fish consumption is a strong predictor of fish consumption (Trondsen et al., 2003; Honkanen et al., 2005; Mitterer-Daltoé et al., 2013a). Emphasizing the importance of fresh fish consumption during childhood (in kindergarten, schools and at home) might be beneficial for increasing fresh fish consumption later in life.

Croatian consumers have a medium level of involvement in cooking. Most of fresh fish consumers neither agree nor disagree that they avoid complicated recipes. According to Grunert et al. (1993) involvement in cooking is negatively 
associated with spontaneity and convenience, while convenience is related to preferring snacks versus meals. Perceived inconvenience of fish is negatively related to fish consumption (Olsen et al., 2007), so convenience orientation and involvement in cooking can be crucial in fish consumption. According to De Rosa et al. (2015), culinary programs can play a role in increasing consumer involvement in cooking. Perceived inconvenience of fish can be decreased through the supply of filleted fish on the domestic fish market.

Furthermore, Croatian consumers do not have strong positive nor negative preferences for wild-caught fish. They are neutral as to the possibility of recognizing differences in the taste of fish. This is also the case of the importance of wild fish species. This is not consistent with previous studies which showed consumer preferences for wild-caught fish (Tidwell and Allan 2001; Schlag and Ystgaard, 2013; Uchida et al. 2014; Claret et al., 2014). On the other side, Verbeke et al. (2007a) showed that the majority of consumers in Belgium reported no perceived differences between farmed versus wild fish. If so, more research is needed on the determinants behind those preferences.

Intrinsic attributes (such as the presence of harmful ingredients, health benefits, capture date, wild versus farmed fish, control certificate, country of origin and dietary composition) are elements that the consumer does not easily or ever assess (Verbeke et al., 2007b) because of the lack of expertise or task difficulty (Grunert, 2005). An individual who does not attach great importance to quality may base his/her decision on attributes like price, expiry date and convenience (preparation) and may use less information cues; while, for the others, the appearance of the fish, control certificate or the possible presence of harmful ingredients can be more important to evaluate quality (Verbeke et al., 2007b).

Significant association was found between some sociodemographic characteristics (gender, age, income level, frequency of physical activity and place raised) and importance of fish farming, which confirms results from previous studies (Drichoutis, et al., 2006; Cardoso et al., 2013; Kaimakoudi et al. 2013; Claret et al., 2014).

Female consumers with higher income and those who were raised in the coastal part of Croatia detect differences in wild and farmed fish during fish consumption more often. These results are also in line with previous studies (Verbeke and Vackier, 2004). In fact, results from Claret et al. (2014) emphasised the segment with a higher openness to farmed fish which was formed mostly by women. The reason why that might be is that they are mainly responsible for food shopping and preparation of food within the household. Anyway, frequency of fish consumption is positively associated with the level of knowledge about fish as a food product (Pieniak et al., 2010), so it can be a possible reason for the association between sociodemographic characteristics and the recognition of differences between wild and farmed fish.

Kaimakoudi et al. (2013) found a "high-potential aquaculture" segment made by consumers with higher income and higher education. This is confirmed partially by the results of this study.

When buying fresh fish, older consumers and those who participate more in physical activity, those who were raised in the coastal part of Croatia, prefer wild fish species. Research results can be connected to the studies of Verbeke et al. (2007a) and Kole (2003): according to them, European consumers perceive farmed-raised fish as being of lower general quality than wild-caught fish. Particularly, a critical driver of consumer perceptions towards food quality and acceptance is a better taste and nutritional values (Cardello et al., 2007). According to previous research (Roberts and Marvin, 2011), older respondents who are physically active care more about food quality because they are more oriented to health (Olsen, 2003) which can be the reason of significant association between age, frequency of physical activity and preferences for wild-caught rather than farmed fish.

The present study confirmed that habits of fresh fish consumption are a significant predictor of preferences for wild-caught fish and consequently of the possibility of detecting differences in wild and farmed fish during consumption (Verbeke and Vackier, 2004; Mitterer-Daltoé et al., 2013b). Verbeke and Vackier (2004) also said that the most important factor which affected fish consumption in Belgium was a habit. According to Mitterer-Daltoé et al. (2013b), low fish consumption may be due to the lack of habit of fish consumption.

Consumers with a higher involvement in cooking prefer fish species that are not farmed and they can detect different flavours of wild and farmed fish during consumption. Possible explanation of these results is that consumers with higher involvement in cooking prepare healthy meals like fresh fish more frequently, which can be associated with a higher level of recognition in the taste of farmed versus wild fish.

\section{CONCLUSION}

The results of the present study revealed that Croatian fresh fish consumers eat fresh fish at home mostly 2-3 times per month. They have a habit of fresh fish consumption but they have a medium level of involvement in cooking. Croatian consumers do not have strong preferences for wild-caught nor farmed fish. Some respondents (females, consumers with higher income and those who were raised in coastal Croatia) more easily detect differences in wild and farmed fish during consumption, while others (older, physically active and those who were raised in the coastal region) prefer wild fish species. Consumers with a higher frequency of fish consumption and a higher involvement in cooking tend to be knowledgeable about fish and tend to prefer wild species. The results of this research could have significant implications for 
the development of marketing communication activities in the aquaculture sector. The design of effective marketing strategies for farmed fish might help increase consumer preferences for farmed fish.

\section{Sažetak}

\section{POTROŠAČKA PERSPEKTIVA: ULOVLJENE RIBE U ODNOSU NA UZGOJENE}

Postoji ograničeno znanje odrednica potrošačkih sklonosti prema ulovljenim (divljim) ribama iz otvorenih voda u odnosu na uzgojene ribe iz ribogojilišta. Ovaj rad ima za cilj istražiti utjecaj sociodemografske strukture, navika i učestalosti potrošnje svježe ribe (kao što je uključenost u kuhanje) na sklonosti potrošača prema ulovljenim u odnosu na uzgojene ribe. Istraživanje je izvršeno na uzorku od 1151 hrvatskog potrošača ribe. Rezultati su pokazali da žene, stariji potrošači, potrošači s višim prihodima i oni koji žive u obalnom dijelu Hrvatske imaju veću preferenciju prema ribi otvorenih voda i mogu prepoznati razlike u okusu ulovljene i uzgojene ribe. Potrošači s većim navikama potrošnje svježe ribe, koji često jedu ribu i više su uključeni u kuhanje, više vole ulovljene ribe otvorenih voda. Ovi rezultati pružaju vrijedne informacije za sektor akvakulture, posebno za planiranje marketinške strategije promicanja uzgoja ribe.

Ključne riječi: svježa riba, hrvatski potrošači, riba otvorenih voda, riba iz uzgoja

\section{REFERENCES}

Alasalvar, C., Taylor, K. D. A., Zubcov, E., Shahidi, F., Alexis, M. (2002): Differentiation of cultured and wild sea bass (Dicentrarchus labrax): total lipid content, fatty acid and trace mineral composition. Food Chemistry, 79, 2, 145150.

Augood, C., Chakravarthy, U., Young, I., Vioque, J., TVM de Jong, P., Bentham, G. (2008): Oily fish consumption, dietary docosahexaenoic acid and eicosapentaenoic acid intakes, and associations with neovascular age-related macular degeneration. The American Journal of clinical nutrition, 88, 2, 398-406.

Barberger-Gateau, P., Jutand, M. A., Letenneuer, L., Larrieu, S., Tavernier, B., Berr, C. (2005): Correlates of regular fish consumption in French elderly community dwellers: data from the Three-City study. European Journal of Clinical Nutrition, 59, 817-825.

Cahu, C., Salen, P., de Lorgeril, M. (2004): Farmed and wild fish in the prevention of cardiovascular diseases: assessing possible differences in lipid nutritional values. Nutr Metab Cardiovas, 14, 34-41.

Cardello, A, Schutz, H, Leshe,r L. (2007): Consumer per- ceptions of foods processed by innovative and emerging technologies: A conjoint analytic study. Innov Food Sci and Emerging Tech, 8, 73-83.

Cardoso, C., Lourenço, H., Costa, S., Gonçalves, S., Nunes, M. L. (2013): Survey into the seafood consumption preferences and patterns in the Portuguese population. Gender and regional variability. Appetite, 64, 20-31.

Claret, A., Guerrero, L., Ginés, R., Grau, A., Hernández, M.D., Aguirre, E., Peleteiro, J.B., Fernández-Pato, C., RodríguezRodríguez, C. (2014): Consumer beliefs regarding farmed versus wild fish. Appetite, 79, 25-31.

Claret, A., Guerreroa, L., Gartziab, I., Garcia-Quirogab, M., Ginésc, R. (2016): Does information affect consumer liking of farmed and wild fish? Aquaculture, 454, 1, 157-162.

Davidson, K., Pan, M., Hu, W., Poerwanto, D. (2012): Consumers' Willingness to Pay for Aquaculture Fish Products vs. Wild-Caught Seafood - A Case Study in Hawaii. Aquaculture Economics \& Management, 16, 2, 136-54.

De Rosa, M., Adinolfi, F., Capitanio, F., Paci, F., Pantini, D. (2015): The role of culinary programs in the emergency of "distinct" consumers. EAAE-AAEA Joint Seminar, 2527.09.2015. Naples, Italy.

Di Turi, L., Ragni, M., Caputi Jambrenghi, A., Lastilla, M., Vicenti, A., Colonna, M.A., Giannico, F., Vonghia, G. (2009): Effect of dietary rosemary oil on growth performance and flesh quality of farmed seabass (Dicentrarchus labrax). Italian Journal of Animal Science, 8, 2, 857-859.

Drichoutis, A. C., Lazaridis, P., Nayga, R. M. (2006): Food involvement and food purchasing behaviour. 98 th EAAE Seminar 'Marketing Dynamics within the Global Trading System: New Perspectives', Chania, Crete, Greece.

Ernst and Young (2008): Evaluation of the common organisation of the markets in fishery and aquaculture products. ANDI- COGEA - Eurofish, European Commission, 2008.

Eurofish Overview of the Croatian fisheries and aquaculture sector https://www.eurofish.dk/index.php/croatia Accessed 9.02.2017.

European Commission (2012): Facts and figures on the Common Fisheries Policy Luxembourg: Office for Official Publications of the European Communities. 1-52. <http:// ec.europa.eu/fisheries/documentation/publications/pcp_ en.pdf> Accessed 05.01.16.

FAO (2004): Food and Agricultural Organisation. The challenge of sustainable production. Available via http://wwx. fao.org/FOCUS/fisheries/challeng.htm

FAO (2014): Food and Agriculture Organization. The State of World Fisheries and Aquaculture. < http://www.fao. org/3/a-i3720e/index.html>. Accessed 15.06.2016.

Food Standards Australia New Zealand (2011): Advice on fish consumption http://www.foodstandards.gov.au/consumer/chemicals/mercury/documents/mif\%20brochure.pdf Accessed 09.02.2017.

Franz, A., Nowak, B. (2010): Functional food consumption in Germany: A lifestyle segmentation study, Discussion Papers, Nr. 1003. 
Fuentes, A., Fernandez-Segovia, I., Serra, J. A., Barat, J. M. (2010): Comparison of wild and cultured sea bass (Dicentrarchus labrax) quality. Food Chemistry, 119, 1514-1518.

Grigorakis K., Taylor K. D. A., Alexis M. N. (2003): Organoleptic and volatile aroma compounds comparison of wild and cultured gilthead sea bream (Sparus aurata): sensory differences and possible chemical basis. Aquaculture, 225, 1-4, 109-119.

Grigorakis, K. (2007): Compositional and organoleptic quality of farmed and wild gilthead sea bream (Sparus aurata) and sea bass (Dicentrarchus labrax) and factors affecting it: A review. Aquaculture, 272, 1-4, 55-75.

Grunert, K. G. (2005): Food quality and safety: Consumer perception and demand. European Review of Agricultural Economics, 32, 369-391.

Grunert, K. G., Brunso, K., Bisp, S. (1993): Food-related life style: Development of a cross-culturally valid instrument for market surveillance. MAPP working paper no 12, October 1993 Available on http://pure.au.dk/portal/ files/88/wp12.pdf. Pristupljeno 23.03.2015.

He, K. (2009): Fish, Long-Chain Omega-3 Polyunsaturated Fatty Acids and Prevention of Cardiovascular DiseaseEat Fish or Take Fish Oil Supplement? Prog Cardiovasc Dis., 52, 2, 95-114.

Honkanen, P., Olsen, S. O., Verplanken, B. (2005): Intention to consume seafood-the importance of habit. Appetite, 45, 2, 161-168.

Jaffry, S., Pickering, H., Ghulam, Y., Whitmarsh, D., Wattage, P. (2004): Consumer choices for quality and sustainability labeled seafood products in the UK. Food Policy 29, 215-228.

Johnston, I. A., Li, X., Vieira, V.L.A., Nickell, D., Dingwall, A., Alderson, R., Campbell, P., Bickerdike, R. (2006): Muscle and flesh quality traits in wild and farmed Atlantic salmon. Aquaculture, 256, 1-4, 323-336.

Kaimakoudi, E., Polymeros, K., Schinaraki, M-G., Batzios, C. (2013): Consumers' attitudes towards fisheries products. Procedia Technology, 8, 90-96.

Kole, A. P. W. (2003): Consumer opinions towards farmed fish, accounting for relevance and individual knowledge. In: Luten, J.B. (eds) Quality of fish from catch to consume Labelling, monitoring and traceability. Wageningen Academic Publishers, Wageningen, 393-400 pp

Luten, J., Kole, A., Schelvis, R., Veldman, M., Heide, M., Carlehög, M., Akse L (2002): Evaluation of wild cod versus wild caught, farmed raised cod from Norway by Dutch consumers. Økonom Fiskeriforsk, 12, 44-60.

Mitterer-Daltoé, M. L., Carrillo, E., Queiroz, M. I., Fiszman, S., Varela, P. (2013a): Structural equation modelling and word association as tools for a better understanding of low fish consumption. Food Research International, 52, 56-63.

Mitterer-Daltoé, M. L., Latorres, J. M., Queiroz, M. I., Fisz- man, S., Varela, P. (2013b): Reasons underlying low fish consumption where availability is not an issue. A case study in Brazil, One of the World's largest fish producers. Journal of Sensory Studies, 28, 3, 205-216.

Olsen, S. O. (2003): Understanding the relationship between age and seafood consumption: the mediating role of attitude, health involvement and convenience. Food Quality and Preference, 14, 3, 199-209.

Olsen, S. O., Scholderer, J., Brunsø, K., Verbeke, W. (2007): Exploring the relationship between convenience and fish consumption: A cross-cultural study. Appetite, 49, 1, 8491.

Pieniak, Z., Verbeke, W., Scholderer, J. (2010): Health-related beliefs and consumer knowledge as determinants of fish consumption. Journal of Human Nutrition and Dietetics, 23, 5, 480-488.

Poli, B. M., Parisi, G., Zampacavallo, G., Mecatti, M., Lupi, P., Gualtieri, M., Franci, O. (2001): Quality outline of European sea bass (Dicentrarchus labrax) reared in Italy: shelf life, edible yield, nutritional and dietetic traits. Aquaculture, 202, 3-4, 303-315.

Rajani, N. (2010): Values, attitudes and intention to consume wild fish versus farmed fish in Nha Trang. Master's Thesis, Nha Trang University, Nha Trang, Vietnam.

Roberts, K., Marvin, K. (2011): Knowledge and attitudes towards healthy eating and physical activity: what the data tell us. Oxford: National Obesity Observatory.

Schlag, K. A., Ystgaard, K. (2013): Europeans and aquaculture: perceived differences between wild and farmed fish. British Food Journal, 115, 2, 209-222.

Smith, W., Mitchell, P., Leeder, R. S. (2000): Dietary fat and fish intake and age-related maculophaty. Arch ophthalmol, 118, 3, 401-404.

Tidwell, J. H., Allan, G. L. (2001): Fish as food: aquaculture's contribution. EMBO reports 2, 11, 958-963.

Trondsen, T., Scholderer, J., Lund, E., Eggen, A. E. (2003): Perceived barriers to consumption of fish among Norwegian women. Appetite, 41, 3, 301-314.

Uchida, H., Onozaka, Y., Morita, T., Managi, S. (2014): Demand for ecolabeled seafood in the Japanese market: a conjoint analysis of the impact of information and interaction with other labels. Food Policy, 44, 68-76.

Verbeke, W., Sioen, I., Brunsø, K., De Henauw, S., Van Camp, J. (2007a): Consumer perception versus scientific evidence of farmed and wild fish: exploratory insights from Belgium. Aquaculture International, 15, 2, 121-136.

Verbeke, W., Vermeir, I., Brunso, K. (2007b): Consumer evaluation of fish quality as basis for fish market. Food Quality and Preference, 18, 4, 651-661.

Verbeke, W., Vackier, I. (2004): Profile and effects of consumer involvement in fresh meat, Meat Science, 67, 159168. 